\title{
A READING OF SATYAJIT RAY'S PATHER PANCHALI AND AGANTUK AS SUBTEXTS OF FICTIONAL ETHNOGRAPHY
}

\author{
Anwesha Dutta Ain \\ Techno International New Town (Formerly Known as \\ Techno India College of Technology), Kolkata (India)
}

\begin{abstract} fictional narratives. Bengal, Fictional Ethnography in Film.

\section{PATHER PANCHALIY AGANTUK, DE SATYAJIT RAY, COMO TEXTOS DE ETNOGRAFÍA DE FICCIÓN}

This essay focuses on Pather Panchali (Song of the Little Road, 1955) and Agantuk (The Stranger, 1991) and discusses the style of Satyajit Ray's filmmaking which combined the aesthetics of European verisimilitude with suggestive symbolism based on conventional Indian iconography. The paper will concentrate on the authentic representation of a poor family in rural Bengal in Pather Panchali and the urban setting, in his last film Agantuk. The main aim is to explore how the detailing of the shots and the dialogues in these films engage in the ethnographic study of the Bengali society through these cinematographic

Keywords: Satyajit Ray, Pather Panchali (Song of the Little Road), Agantuk (The Stranger),

\section{Resumen}

Este ensayo estudia Pather Panchali (La canción del camino) (1955) y Agantuk (El extraño) (1999) y detalla el estilo cinematográfico del director indio bengalí Satyajit Ray, que combinó estilo europeo con un simbolismo basado en iconografía típica india. El trabajo se centrará en la representación de una familia en un entorno rural, en Pather Panchali, y en un entorno urbano en la última película de Ray, Agantuk. El objetivo es señalar los planos y los diálogos que permiten que estas películas puedan ser consideradas estudios etnográficos de sociedades bengalíes en narrativas de ficción cinematográficas.

Palabras Clave: Satyajit Ray, Pather Panchali (La canción del camino), Agantuk (El extraño), Bengala, etnografía en ficción cinematográfica.

DOI: https://doi.org/10.25145/j.recaesin.2021.83.06

Revista Canaria de Estudios Ingleses, 83; November 2021, pp. 77-90; ISSN: e-2530-8335 
Akira Kurosawa once remarked, "not to have seen the cinema of Ray means existing in the world without seeing the sun or the moon" (qtd Jasper 126). Satyajit Ray, who can be simultaneously described as a visionary, film director, scriptwriter, music composer, author, graphic artist, editor, lyricist and undoubtedly much more, had penned on filmmaking, focusing especially on the predicaments faced by Indian filmmakers. In 1948, even before he had started shooting for his first feature film, Pather Panchali (Song of the Little Road) (1955), he lamented the state in which Indian cinema then was, and wrote:

What the Indian cinema needs today is not more gloss, but more imagination, more integrity, and a more intelligent appreciation of the limitations of the medium. [...] What our cinema needs above everything else is a style, an idiom, a sort of iconography of cinema, which would be uniquely and recognisably Indian. (1976: 22)

So, when Ray first conceptualised Bibhuti Bhushan Bandyopadhyay's novel, Pather Panchali (translated into English in 1968, and published under the title Pather Panchali. Song of the Road) as a film that he wanted to make, it could be expected that the audience would have an Indian story told in an essentially Indian way.

To the question by interviewers as to who had influenced him the most in his works, Satyajit Ray always mentioned the name of Robert J. Flaherty amongst others (1976: 54). Flaherty, who is commonly regarded as the 'father' of both documentary and ethnographic films, was the first director whose documentary film, namely Nanook of the North (1922) witnessed considerable commercial success. The film combined the elements of both drama and documentary, thus paving the way for the development of the genre of filmic ethnography. As early as 1957 and ' 58 , critics like Robert F. Hawkins and John Updike drew parallels between Flaherty and the element of fictional ethnography in Ray's technique of filmmaking, which was characterised by precision in observation and focus on grounded reality. After Venice Film Festival in 1957, Hawkins wrote about how Ray's "direct yet poetic observation of the human scene recall[s] the best work done [...] by Flaherty." While writing for the Harper's Magazine in 1958, Updike included Pather Panchali "in the great tradition of documentary carved out [...] by our own Bob Flaherty." Ray's fictional ethnography lies in the way he chronicles Bengali life with the precision of a documentary film that is enhanced with the art of storytelling.

Ray is a patient, observant insider insistently documenting the micronarratives of ordinary individuals and their day-to-day struggle. His camera is sometimes the invisible observer, like in the sequence of the rainy season in a Bengal village in Pather Panchali (01:33:08-01:40:10), and sometimes a participant in the story, like in the shooting of the dance ritual by the Santhals near the end of Agantuk (01:49:34-01:54:04). The dynamics of the power structures involved in the observer-observed relationship dissipates in Ray's films as he plays the role of both insider and outsider. Gregory Bateson, the interdisciplinary scientist, who challenged the way conventional anthropologists observed and recorded their subjects, remarked: 
They [scientists and anthropologists, whom Bateson called the Functional School] have described the structure of several societies and shown the main outlines of the pragmatic functioning of this structure. But they have scarcely attempted the delineation of those aspects of culture which the artist is able to express by impressionistic methods. [...] Evidently then the emotional background is casually active within a culture, and no functional study can ever be reasonably complete unless it links up the structure and pragmatic working of the culture with its emotional tone or ethos. (2)

Ray's films potentially lend themselves to be understood as ethnographic fiction as he artistically captures the whole emotional tone or ethos of a society in a manner that goes beyond the mechanics of formal, organized anthropological research. In this context of depicting a society, the detailing of a scene he was shooting, as the director himself told us, was of paramount imimportance to him: This is Indian tradition. It's very, very important the presence of the essential thing in a very small detail, which you must catch in order to express the larger thing.

This is in Indian art, this is in Rajput miniatures, this is in Ajanta, this is in Ellora, this is in the classics, in Kalidasa, in Sakuntala, in folk-poetry, in folksinging. This is the the essence, I think (1970: 120).

Pather Panchali tells us the story of a rural family neck-deep in poverty set in one of the villages of Bengal, where the little boy Apu is born and starts to develop his first sensibilities of responses to the world around him. His sister Durga dies in a devastating monsoon that wreaks havoc at the poor hut, and his Auntie Indir Thakrun is cruelly left at the mercy of nature to die alone in the forest. His parents Harihar and Sarbojaya finally leave their village. Ray's first film turned out to be an artistic expression, with powerful images of humanity and created with an exemplary economy of means.

The oeuvre of Ray's films expanded over four decades, from 1950 to 1990, coinciding with the transition of the Bengali society from an agricultural economy to a capitalist culture. If all his thirty-six films were read as one single text, they would offer a remarkable fictional ethnography of the shift in Bengali society from agrarian culture to bourgeois values. His last film, Agantuk, much unlike his first, is a tragic story of an Uncle who comes back to visit his niece and her family after thirty-five years of absence, while he went globe-trotting and was engaged in anthropological research. It is often considered to be Ray's own commentary on the sorry state of affairs with human life and humanity, akin to Rabindranath Tagore's last essay, Crisis in Civilisation (1941), written during the distressful times of World War II. Through Manmohan, the protagonist, Ray asserts that it is experience and conventional textual education that have put mankind in a situation where he constantly corrupts and mutilates himself despite all the sophistication of civilisation. The inevitable and ominous question with which the audience leaves the theatre is what, then, civilisation is. From the nuanced portrayal of the human condition in rural Bengal in Pather Panchali, Ray's films traversed a long way into the classy drawing-room of a refined Bengali middle-class family in the heart of the city in Agantuk, and the narrative of fictional ethnography comes a full circle, as this man must return to the 
remote village of the Santhals in Shantiniketan to live under non-urban conditions, which he considers nobler than that of an erudite urban gentleman.

The gradual but stark transformation in the emotions and responses of characters to events around them from the early 1950s to the late 1980s is evident in the way Sarbojaya, in Pather Panchali, expressed her disgust at Indir Thakrun's pleading for a new shawl (00:29:44-00:30:08) or in the way Sudhindra, in Agantuk, questions the credulity of the Uncle when the latter offers no plausible motive for his sudden visit (00:03:23-00:08:12). The subtext of his films holds a mirror to the collective consciousness of the society, especially the Bengali society in West Bengal. However, while they bear unmistakable stamps of the times in which they were made, Ray's films undeniably depict human emotions that are universal, and that is precisely where the complexity of his craft lies. The intricate detailing of the inanimate objects on the set were of utmost importance to the director, who was determined never to make a compromise on either the mood of the scene he was filming or the ethos of the story he was telling. Amaresh Misra, while elaborating on the techniques used by Ray, comments:

[I]n them [Ray's films], elements of 'concrete setting' and 'open space' fused to form a living environment [.] In this, technical elements too took on a new role: the camera for instance by literally waiting for the 'texture' of a setting to unfold before moving on, in a very measured tempo, to link the inanimate objects, symbols, etc, with the actions of the character ensured that aspects of 'information' filling up the environment would throb with a life of their own. (1052)

In this context, one might recall the sequence in Pather Panchali that portrays natural elements with a movement of the camera which can be likened to a little boy running through the village paths: the dragonflies and the waterskaters scouting the twigs growing in the pond (01:33:08-01:34:42), and then finally the camera moving on to capture the scene where the bald-headed villager becomes alert of the onset of the rainy season when the first raindrop falls on his pate (01:37:14-01:37:47). This entire sequence of "grey humid stillness" (1976: 34), as Ray himself described it, accompanied by Ravi Shankar's sitar music as the background score, heralded the monsoon not only in the village of Nishchindipur on screen, but also in the imagination of the audience. Mahdi Chowdhury rightly points out that "Ray's genius lay in his ability to capture an ethnographic portrait of Indian village life."

Without dialogue or movement of the characters, Ray induced the desired temper in his audience for the playfulness of Apu and Durga drenched in the first monsoon rain (01:37:49-01:40:10), and yet the heightened pathos, that is the very essence of the film, was not entirely whisked away. As Ray was always pressed for funds during his shooting of Pather Panchali, he had to balance this new form of cinema in the India of the 1950 s with other modalities of shooting. Ray talks about these conditions stating:

It was very unpleasant. It meant, for one thing, that we missed the rainy season, and we had to shoot the rain scenes in October. Throughout the rainy season we 
had no money. It meant going to the location every day with the entire crew and cast and just waiting. There were days and days of waiting and doing nothing... We would keep looking at the sky and at little patches of cloud which wouldn't produce any rain. (qtd Robinson 84)

Ray was so intent to capture the scenes in their true natural setting that he would rather undergo this ordeal than shoot the film in a studio setup. He had deplored the habit of Indian filmmakers of "shooting indoors in a country which is all landscape" (1976: 23). Given the times in which his first film was made, Ray was doing ground-breaking work: no one in Indian cinema till then had ever thought of either portraying the tatters of a penniless family without embellishment and gloss nor did anyone here ever fancy of casting an eighty-year-old woman without a semblance of makeup. However, he was careful not to cross the fine line between romanticising poverty and the aesthetics in the portrayal of it. I quote from an interview given by Ray in 1981 to Cineaste:

Cineaste: Some critics feel that you romanticize poverty, that the poverty and misery in your films never becomes ugly.

Ray: I think that Pather Panchali is fairly ruthless in its depiction of poverty. The behaviour of characters, the way that the mother behaves towards the old woman, is absolutely cruel. I don't think anyone has shown such cruelty to old people within a family. (1982: 29)

Ray's work, especially because of the choices he makes in casting and because of the experiential manner in which he takes the shots, becomes ethnographically important. Interestingly enough, Pather Panchali, as Andrew Robinson tells us, never had a proper script (76). Ray began imagining the film shot by shot, in intricate detail, while he was travelling by ship from London. Since early 1952, he started to sketch the most important shots in black ink, and he kept in his head the dialogues of the film, most of which were taken from Bandyopadhyay's novel. As he started shooting the film in the village in Boral, miles away from Kolkata, Ray took filednotes from what he observed: the conversations of the rural folks, their way of dealing with life in utter poverty, their responses to natural events like the rainy season, the way a death in the family affected the people in it and so on. Much of these observations were imbibed into the shooting of the film, as Ray wanted to ensure that he portrayed the Bengali rural life in its authentic detail. Ethnographic studies in recent times, as George Marcus tells us, has stretched beyond the conventions of formal, trained fieldwork:

Ethnography moves from its conventional single-site location, contextualized by macro-constructions of a larger social order, such as the capitalist world system, to multiple sites of observation and participation that cross-cut dichotomies such as the "local" and the "global," the "lifeworld" and the "system." (95)

As the camera observes the minute detail of the characters and the setting with precision, Ray's films offer us a perspective into the Bengal of his times through 
the narration of micro-stories. Later, in 1957, after he had completed the film and it was received with accolades both in his home country and abroad, he wrote:

I chose Pather Panchali for the qualities that made it a great book: its humanism, its lyricism, and its ring of truth [...] The script had to retain some of the rambling quality of the novel because that in itself contained a clue to the feel of authenticity: life in a poor Bengali village does ramble. (1976: 33)

The adaptation of the novel, which was "a kind of encyclopaedia on Bengali rural life" (1976: 33) was not a linear task that Ray had undertaken. Ray had spoken about the complexity of the problem in adapting to film a novel that abounds in long, exquisite descriptions of the village landscape:

You had to find out for yourself how to catch the hushed stillness of dusk in a Bengali village, when the wind drops and turns the ponds into sheets of glass, dappled by the leaves of saluk and sapla, and the smoke from ovens settles in wispy trails over the landscape, and the plaintive blows on conchshells from homes far and near are joined by the chorus of crickets, which rises as the light falls, until all one sees are the stars in the sky, and the stars that blink and swirl in the thickets. (1982)

The sketches of the characters and settings that Ray made in his notebook are now available in print, namely, The Pather Panchali Sketchbook. It shows how Ray collected detailed field-notes from his expeditions in the village of Boral and from the conversations of the villagers there. His camera thus acts as a character, as it observes life in minute detail while at the same time participating in the scene it is filming. Ray, by means of his creative imagination, improvised Bandyopadhyay's fictional narrative in a manner where the characters on screen played their parts, uninterrupted, as members of that social group in the village. Pather Panchali thus reflects the genuine ethos of rural Bengal and capture the great humanist experience, making the film a fictional ethnographic study on the villages of Bengal during the middle of the twentieth century. It may be mentioned here that the film won the "Best Human Document' award in 1956 Cannes Film Festival, an improvised award that was never given to any other film before or since (Chowdhury).

Ray relied heavily on the interplay of contrasts that focused on the carefully calculated refinement of certain fundamental sequences. Three such instances which may be brought to the fore in this context constitute in the situation where Durga tries to amuse her Auntie Indir Thakrun with a fruit stolen from the neighbour's orchard, and her mother Sarbojaya reprimands her for the very act of stealing (00:07:51-00:08:49). The second scene is where Apu and Durga almost dance away gleefully through the village paths and are brimming with the ecstasy of life as Indir Thakrun dies (01:17:15-01:19:43). Thirdly, the scene where Harihar, on returning home after several months, contentedly hands over the gifts to Sarbojaya only to find that his daughter has died during his absence (01:51:10-01:55:25). In Pather Panchali, the audience first sees Sarbojaya bemoaning the death of her daughter only months after her actual demise, when her husband returns home (01:54:3301:54:55). The delayed response of the mother displays the resilience of the woman 
who was in charge of keeping the family together with the little means she had had in the absence of the husband in the household. There are various moments in the film which can be cited as examples of Ray's unique way of capturing emotive responses. Namely, in the sequence where Sarbojaya's wailing is expressed not by her own voice nor by any human voice, but by the high-pitched notes of the tarshehnai (a musical instrument very similar to an esraj). Throughout this sequence, high notes of the tarshehnai played by Dakshinaranjan Tagore in raga 'Patdeep' run as the background score. It was Ray's idea to shoot the scene in this way, and none other than Ravi Shankar selected this particular raga to be played. The music invested the scene with far more potency than any word or wail possibly could. This scene is an example of the ethnographic study of the space between great historical events and the realities that the director/ethnographer is faced with in the field.

As Michelangelo Paganopoulos points out:

Anthropologically, Ray's world cinema anticipated the "third space" of ethnographic imagination, in-between great historical events and grounded truths picked from the field (389).

This ethnographic study is clear in his last feature film, Agantuk (1991). The main difference is that Agantuk, unlike Pather Panchali, relies heavily on dialogue. Agantguk has only two musical sequences: one, when Anila sings a Tagore song for the guests in her house and the other when the Santhal tribes put up a dance-show for the Uncle. Darius Cooper has written about Ray's last three films, pointing out:

In Ray's 1990s trilogy [Shakha-Proshakha (Branches of the Tree) (1990), Ganashatru (An Enemy of the People) (1989) and Agantuk], the spoken word becomes the most prominent "signifier of the social, political and cultural struggle" in which his characters are embroiled. The "words and propositions" expressed by the speakers "change their meanings according to the positions the characters are shown holding" either at the center or at the margins; and it is in "reference to their positions" and through their utterances that Ray finally makes his characters arrive at their own meanings of being and becoming. (219-220)

One is rather tempted to dub the film a discourse on what is civilization, particularly because of a long sequence where Sudhindra's friend, Prithwish, engages in a diatribe with Uncle, Manmohon Mitra (01:15:55-01:30:50). In one of the reviews of the film published in The New Yorker, shortly after Ray's death in 1992, the reviewer wrote that it was "a modest picture, a graceful domestic comedy made in a serene, leisurely classical style" (Rafferty 79). Manmohon narrates the experiences of his travels and the times he has spent with the indigenous tribes of India and the United States at various points of time in his life during the long thirty-five years of his absence. In doing so, he expresses his personal opinions on matters ranging from the true definition of science and the misuse of technology to religion, caste, creed and finally on the question of the nobility of the savage. Critics have written at length on the anthropological calling which refers to the auteur himself: 
The four decades of the uncle's absence echo the four decades of the director's work. For those familiar with Ray's films, the opening sequence of Agantuk feels as if the boy-trickster Apu, from his world-famous debut Pather Panchali ('Song of the Little Road', 1955), grew up into an 'anthropologist'. [Ray is described] as an auteur whose work not only critically reflected upon the history and society of his time, but recontextualized 'India' within our globalized world society. (Paganopoulos 372)

However, while making the Uncle mirror the persona of Ray himself more than any other character in his films, Ray never departed from the authentic representation of Bengali culture and ethos. In the film, Manmohon Mitra decided to give up his plans of joining art school when he came across a foreign magazine which featured an astonishing painting of a bison by the cave-dwellers of Altamira from some 2000 years ago. Both Manmohon and Ray share a keen anthropological interest that is conspicuously reflected in the former's travels among the indigenous tribes in different parts of the world and the latter's unique art of filmmaking that blends documentary and fictional film through thick descriptions and conversational narratives. Both men denounce specialisation in formal academics and seek knowledge with an unmatched openness of mind in realms as varied as technology, social sciences and arts. Andrew Robinson aptly comments that, in Agantuk, "Ray made the equivalence between himself and the main character so plain that there could be no doubt (355-356)." It may be argued that his last film was an attempt on his part to fulfil his wishes of anthropological travels and research through the character of Manmohon, who is portrayed as an anthropologist in the film. Like Manmohon, Ray also presents to his audience the field-notes that he picks up from the ground reality of the characters he is portraying, and this is what makes his films a veritable register of ethnographic study of Bengal.

One may begin to elaborate on the point of accurate detailing of the representation of Bengali culture by starting to talk about the setting of the film. Most part of the film is shot inside the Bose household, a quintessential Bengali middleclass family in an urban area, where the gentleman husband holds an honourable position in an organisation, the wife keeps the house with two domestic helps under her command, and the child is a regular school-goer. Sudhindra perfectly fits the Bengali notion of a 'bhadralok': he is learned, earns a handsome salary, is caring about his wife and son, and has the essential quality of what Ray calls "social diplomacy"1 $(00: 40: 24-00: 40: 30)$ that is the hallmark of Bengali middle-class culture. The wife, Anila, is educated, polished and cultured, yet humane and down-to-earth, cherishes her husband, and responsibly carries out her duties towards her family. Her manners are measured so as to reflect the strength of her personality and yet not show arrogance. The son, Satyaki (Bablu is his nickname), is a happy, delightful

${ }^{1}$ Ray added subtitles in English to his own films. The Bengali 'bhadralok' or 'gentleman' necessarily is characterised by what in Bengali is called 'samajik chokkhulojja' (00:40:24-00:40:30), which does not have a literal or parallel English word. Ray translated it as "social diplomacy," and I follow his description. 
child. His actions never fail to illustrate the curiosity and sensitivity in his nature. Characters like Sudhin, Anila and Satyaki were common among the Bengali gentry in the 90s Kolkata. In his 1970 interview with Folke Isaksson, Ray mentioned:

$[Y]$ ou have to have the backing of your own culture very much. Even when I made my first film the awareness was there. I had a Western education, I studied English, but more and more over the last ten years I have been going back and back to the history of my country, my people, my past, my culture... (1970: 119)

As time elapsed, this journey of going back to his own roots became an emphatic motif in Ray's works. For instance, while shooting the sequence of the tribal dance towards the end of Agantuk, the camera becomes almost possessed by the rhythm of the dancers during the ritual celebration. Simultaneously, the character Anila becomes a tool in Ray's ethnographic research, as she, with encouragement from her husband, eventually participates in the dance with the Santhal tribes (01:49:34-01:54:04) and brings herself closer to "become like a savage" and feel "closer" to the Uncle (01:38:36-01:38:43).

The change of heart in Sudhin, who was previously suspicious of the Uncle, may be interpreted as Ray's allegiance to the anthropologist who is trying to live a life close to nature, like that of the tribals. Just like a practising ethnographer grounds his study on the field-notes he has taken, Ray picks up the characters of his film from the people he meets and observes. His portrayal of people is realistic because he does not add traits to his characters or mould them in order to suit the purpose of his story; rather he fashions his stories the way they might happen with the people he sees around him. That is one of the main reasons his films can be read as a subtext of fictional ethnography.

Moderation in manners as well as in décor was the distinctive feature of a learned Bengali family (what in Bengali is called 'bhadra samaj') living in the 90s Kolkata. The rare and valuable collection of art that Sudhindra's father owned points to the opulent heritage of the family. The family friends, actor Ranjan Rakshit and his wife Chhanda, or Prithwish Sengupta, who is a barrister, serve their roles not only as foils to the Bose family, but also are typical portrayals of the Bengali gentry. Through the portrayal of these characters, Ray makes a strong commentary on such people in society who are egotistical and conceited. The characters and the setting bespeak an essentially Bengali culture of a certain section of the society during the times in which the film was made. V.S. Naipaul, the Noble Prize-winning author, placed the art of Ray and that of Kurosawa in the same high standing, and fittingly observed:

They are not, like the Americans, looking for a property. They are doing on film what the old novelists of the nineteenth century did. They are describing their societies, their cultures, in the modern medium. Their work hangs together; it's about their view of the world, being given in different ways at different times. (109)

Another important aspect of Agantuk is the pun implicit in the dialogues. Many pivot on words in Bengali, and a Bengali man, with the depth of erudition and 
wit like that of Manmohon, often did engage in such play of words in his everyday life. Interestingly, Ray invests only Manmohon's dialogues with such puns, and not that of any other character in the film, thus remaining truthful to the society and culture he depicted in the film. I will focus on three instances to prove that Ray here studies ethnographically the middle class of urban Kolkata.

Firstly, when Manmohon shows coins from different Western countries to Satyaki, the little boy is both happy and amazed to be able to touch and see such things presumably for the first time in his life (00:25:01-00:25:46). As Satyaki moves to hand them over to Manmohon, he refuses to take them back, explaining that he had been to those countries of which these coins are currencies, but he is not a numismatist, and so he is gifting Satyaki these foreign coins. In his dialogue, he uses the word 'mudradosh', which is a Bengali word for 'mania, or peculiar habit'. But there is more to it than literal translation. In Bengali, the word 'mudra' separately means 'currency' and 'dosh' may refer to either a 'mistake' or, sometimes, a 'bad habit'. So, only a Bengali with fair knowledge of the language would be able to appreciate the play of words latent in the dialogue.

Secondly, in the drawing-room sequence (01:09:40-01:11:53), where Sudhin, Anila, Prithwish and Manmohon are present, tea is served with tasty home-made biscuits, and it is a common habit of male friends in a gathering like this to light a cigarette while relishing the hot beverage. Yet it is a prominent custom among Bengalis, or for that matter, among Indians, to not smoke in front of elderly persons; smoking in the presence of one's elder or superior is conventionally considered a mark of disrespect. Manmohon, with his liberal thoughts and original ideas, and with such varied experience of spending time with different sects of aborigines in India and in the US, is, of course, beyond such orthodoxy. He openly urges Sudhin and Prithwish to smoke a cigarette, if they want to, and adds a witty rejoinder, saying that he does not believe "in this show of respect in front of elders," and that if they "don't count [him] as an elder, [he'll] certainly not sit in judgement" (01:10:3601:10:46). Again, Ray plays here with words. Manmohon, in Bengali uses the word 'guru', meaning teacher or elderly or priest and chief or important, in an alliterative manner. His words literally could be translated as follows: if they do not regard him as 'guru', it is not a 'gurutaro' (here meaning 'grave' or 'serious') offence. The remark is evidently a subtle hint at the identity and credibility of Manmohon that Sudhin and Prithwish harbour in their mind. Though Sudhin tries his best to hide his suspicion under the garb of social diplomacy, frequently his words or manners betray him. Manmohon, with all his intelligence and experience, can easily sense the disapproval, and handles the awkward situations with the tactful use of wit. These play on words and display of wit were not uncommon in a learned Bengali household and so they represent the manners and mannerisms of a section of the society whose story Ray was telling.

Thirdly, there is another pun, rather inter-lingual, in the reference to the acronym NASA which connects to 'nesha', the Bengali word for 'addiction'. As I have pointed out earlier in this essay, the long diatribe in which Prithwish engages against Manmohon is replete with many shades of ideas on what civilisation is. Manmohon rhetorically compares the progress of the man sitting in a privileged position within 
the luxury of plush interiors and pressing a single button to remotely obliterate whole cities with the progress of the tribal warrior who fashions his weapons from natural elements and depends on his own instincts to protect his men (01:28:40-01:29:01). As Prithwish prods him to express his opinion on the advancement in science and technology by NASA, his caustic remark pivots on the word 'nesha', a conspicuous hint at the addiction, used here in all its negative connotation (01:17:45-01:18:22). He refers to the so-called civilised men, to the progress of science and technology. The necessity of such technologically acclaimed feats is juxtaposed against the essential skills for survival (hunting, fishing, farming, weaving, pottery among others) that indigenous tribes have developed over centuries without formal education. Manmohon cites the examples of the Eskimo who builds his igloo with two different types of ice according to the purpose of specific areas, or the tribal people who build a hut with mud, leaves and thatched roof as the shelter for their folks (01:24:4801:25:56). He goes on to say that erecting a hut is no less a technical achievement than the accomplishments of NASA. Like in the previous two examples, no subtitle can ever do justice to the allusion loaded in the use of the word 'nesha' in connection with NASA, an epitome of modern technological progress. Despite such linguistic interplay in the Bengali language, what makes Ray's films universal in their appeal is the sensitive treatment of human emotions, which audience from any part of the world can relate to. Robin Wood, the influential film critic, while speaking of the reception of Ray's films among Western audience, wrote:

In terms of general subject-matter Ray's films usually deal with human fundamentals that undercut all cultural distinctions [...] When a specific cultural peculiarity does play a part in the narrative it often becomes evident that the attitude to it encouraged by the film as a whole, is not all that far removed from our own. (7)

Early in 1992, the Academy of Motion Pictures awarded a special Oscar to Ray in recognition of his "rare mastery of the art of motion pictures and for his profound humanitarian outlook, which has had an indelible influence on filmmakers and audiences throughout the world" (Sengoopta 247). Shortly thereafter, speaking to the Time Magazine from his hospital bed, Ray made perhaps the most apt remark about his own films:

The most distinctive feature [of my films] is that they are deeply rooted in Bengal, in Bengali culture, mannerisms and mores. What makes them universal in appeal is that they are about human beings. (1992)

Writing about Satyajit Ray's films in 1996, Amartya Sen argued that the sense of humanism that pervades all of Ray's films essentially calls into question the fixed cultural notions of Western modernism:

These approaches share, to varying extents, a well-articulated "anti-modernism," rejecting, in particular, "Western" forms of modernization, which Chatterjee [Partha Chatterjee, in his book, The Nation and its Fragments] contrasts with the preferred form of what he calls "our modernity." Sometimes the defiance of Western 
cultural modes is expressed in India through enunciations of the unique importance of Indian culture and the traditions of its communities. (28)

Ray's ideas, as Sen rightly opined, even today are central to the great cultural debates current in the literary and intellectual circles of the present day. Ray's films are situated at a very interesting juncture of his culture as an Indian gentleman, the Western education he was initiated into at Shantiniketan and his own identity as a Bengali. Ray's ideas, his philosophy, his humanism, and the expression of his art drew heavily upon Tagore's ideals and teachings. Time and again, Ray had referred to the 8-line poem, now famous, that Rabindranath Tagore wrote for Manik (Ray's pet-name), when his mother took him with her to visit the poet in Shantiniketan and he pleaded with Tagore to write something in his new autograph book (Jokhon Chhoto Chhilam 36-37). The poem reflects on the vanity of the great expeditions of the poet to the distant lands, the faraway mountains and the far-off oceans, while the exquisite beauty of the single drop of dew on a blade of grass: "a dewdrop which reflects in its convexity the whole universe around you" (1970, 120), next to his home remain undiscovered to him. In 1991, in the last English article that would be published before his death, Ray commented on the significance and relevance of this small poem to his work in particular and to Indian art in general,

Santiniketan made me the combined product of East and West that I am. As a film-maker I owe as much to Santiniketan as I do to American and European cinema. And when I made my first film, Pather Panchali, and embellished it with rural details which I was encountering for the first time, Tagore's little poem in my autograph album came back again and again to my mind. (1991)

It is fascinating to note that Ray wrote this for The Guardian on the occasion of the fiftieth death anniversary of Tagore, shortly after shooting the penultimate sequence of Agantuk in Dopukuriya, a Santhal village on the outskirts of Shantiniketan, where Ray used to sit and draw buffaloes as a young art trainee. Of Tagore and Ray, Madhabi Mukherjee, the eminent actor who was the heroine of Ray's Charulata and probably also his unfulfilled love interest, had once said: "They were the two great titans of our cultural life" (29). The syncretism of the East and the West, that is the essence of Tagore's works and philosophy, is also profoundly reflected in Ray's cinematic endeavours. As he himself mentioned, he was "in a way a kind of product of East and West" (1970: 119). Ray, like Tagore, collected his 'fieldnotes' from the people he met around him and the places he went to. His artistic forms of representation took a step forward from Tagore, as he took to cinema. 


\section{WORKS CITED}

Agantuk. Dir. Ray, Satyajit. National Film Development Corporation of India, 1991.

Bandyopadhyay, Bibhutibhushan. Pather Panchali. Dey’s Publishing, 2015[1929].

Bandyopadhyay, Bibhutibhushan. Pather Panchali. Song of the Road. Trans. T.W. Clark \& Tarapada Mukherji. Allen \& Unwin-UNESCO, 1968.

Bateson, Gregory. Naven: A Survey of the Problems suggested by a Composite Picture of the Culture of a New Guinea Tribe drawn from Three Points of View. Stanford University Press, 1958 [1936 $2^{\text {nd }}$ ed.].

Charulata. Dir. Satyajit Ray. R.D. Bansal \& Co., 1964.

Chatterjee, Partha. The Nation and its Fragments: Colonial and Postcolonial Histories. Princeton University Press, 1993.

Chowdhury, Mahdi. "Not quite Satyajit Ray's World: Looking back at early critics' cold reception of the filmmaker's seminal work.” Himäl Southasian (11 July 2018). https://www.himalmag.com/not-quite-satyajit-rays-world-early-western-critics-cold-reception/. (Accessed 20 May 2021).

Cooper, Darius. The Cinema of Satyajit Ray: Between Tradition and Modernity. Cambridge University Press, 2000.

Ganashatru. Dir. Satyajit Ray. National Film Development Corporation of India, 1989.

Hawnins, Robert F. "Venice Festival in Retrospect." The New York Times (15 September 1957).

JASPER, David. “'What happened in the Cave?' Communities and Outsiders in Films of India." Imag(in)ing Otherness: Filmic Visions of Living Together. Ed. S. Brent Plate \& David Jasper. Scholars Press, 1999. 123-132.

Marcus, George E. "Ethnography in/of the World System: The Emergence of Multi-Sited Ethnography.” Annual Review of Anthropology 24/1 (1995): 95-117. doi: https://doi. org/10.1146/annurev.an.24.100195.000523. (Accessed 23 May 2021).

Misra, Amaresh. "Satyajit Ray's Films: Precarious Social-Individual Balance." Economic and Political Weekly 27/20-21 (16-23 May 1992): 1052-1054. JSTOR, https://www.jstor.org/ stable/4397887. (Accessed 17 May 2021).

Mukherjee, Madhabi. My Life, My Love: An Autobiography. The Stanford Theatre Foundation, 1999.

NaIpaul, V.S. “Contribution to Satyajit Ray at 70.” Nemai Ghosh, Eiffel Editions, 1991.

Nanook of the North. Dir. Robert J. Flaherty. Pathé Exchange, 1922.

Paganopoulos, Michelangelo. "The Changing World of Satyajit Ray: Reflections on Anthropology and History." Media Watch 11/2 (2020): 371-393. doi: https://doi.org/10.15655/mw/2020/ v11i2/195663. (Accessed 15 May 2021).

Pather Panchali. Dir. Satyajit Ray. Government of West Bengal, 1955.

Rafferty, Terrence. “Legacy.” Rev. Agantuk (Dir. Satyajit Ray). The New Yorker (18 May 1992): 79.

Raina, Raghunath. Foreword. Satyajit Ray: An Anthology of Statements on Ray and by Ray. Ed. Chidananda Dasgupta. Directorate of Film Festivals, Ministry of Information and Broadcasting, 1981. 7.

RaY, Satyajit. Bisay Chalachchitra. Ananda Publishers, 1982. 
RaY, Satyajit. "Conversation with Satyajit Ray.” Interview by Folke Isaksson. Sight and Sound 39 (Summer 1970): 114-120.

RaY, Satyajit. Interview with Satyajit Ray. Télérama (24-30 August 1991).

RaY, Satyajit. Interview with Satyajit Ray. Time (6 January 1992).

Ray, Satyajit. Jokhon Chhoto Chhilam. Ananda Publishers, 2008[1982].

Ray, Satyajit. "My Life, My Work." The Telegraph (27 September-1 October 1982), in five parts (Amal Bhattacharjee Lecture delivered on 21 September 1982). Republ. Tarapada Banerjee. Satyajit Ray: A Portrait in Black and White. Viking, 1993. 15-28.

RaY, Satyajit. Our Films Their Films. Orient BlackSwan, 2016[1976].

RaY, Satyajit. Satyajit Ray on Cinema. Ed. Sandip Ray. Columbia University Press, 2011.

RaY, Satyajit. "The Home and the World." The Guardian (1 August 1991).

Ray, Satyajit. The Pather Panchali Sketchbook. Ed. Sandip Ray. Harper Collins \& Soc. for the Preservation of Satyajit Ray Archives, 2016.

RaY, Satyajit. “The Politics of Humanism: An Interview with Satyajit Ray.” Udayan Gupta. Cinéaste 12/1 (1982): 24-29. JSTOR, https://www.jstor.org/stable/41686766. (Accessed 16 May 2021).

Robinson, Andrew. Satyajit Ray: The Inner Eye. Biography of a Master Film-maker. I.B. Tauris, 2004.

SEn, Amartya. "Satyajit Ray and the Art of Universalism: Our Culture, Their Culture." The New Republic (1 April 1996): 27-34.

Sengoopta. Chandak. “The Movies: Satyajit Ray: The Plight of the Third-World Artist.” The American Scholar 62/2 (Spring 1993): 247-254. JSOR, https://www.jstor.org/stable/41212100. (Accessed 15 May 2021).

Shakha-Proshakha. Dir. Satyajit Ray, performed Ajit Banerjee, Haradhan Banerjee, Soumitra Chatterjee, Dipankar Dey, Lily Chakravarty, Mamata Shankar. Satyajit Ray Productions, 1990.

TAgore, Rabindranath. "Bohu din dhore." 1929. Qtd Jokhon Chhoto Chhilam. Satyajit Ray. Ananda Publishers, 2008[1929]. 37.

TAGORE, Rabindranath. Crisis in Civilisation. Visva-Bharati. 1964[1941].

Updike, John. “After Hours.” Harper's Magazine (1 May 1958).

Wood, Robin. The Apu Trilogy. Praeger Publishers Inc., 1971. 